\title{
Lipid changes in patients receiving nevirapine (NVP) in combination with tenofovir/emtricitabine: results from the CCIAT trial C Davis*1, R Talwani1 ${ }^{*}$ B Gilliam¹, A Amoroso1, C Boyce ${ }^{2}$, P Piliero ${ }^{3}$, C Conner ${ }^{3}$ and R Redfield ${ }^{1}$
}

Address: ${ }^{1}$ Institute of Human Virology/University of Maryland School of Medicine, Baltimore, MD, USA, ${ }^{2}$ Institute of Human Virology, Baltimore, MD, USA and ${ }^{3}$ Boehringer Ingelheim Pharmaceuticals Inc, Ridgefield, CT, USA

* Corresponding author

from Ninth International Congress on Drug Therapy in HIV Infection

Glasgow, UK. 9-13 November 2008

Published: 10 November 2008

Journal of the International AIDS Society 2008, I I (SuppI I):PI 2 I doi:I0. I I86/I758-2652-I I-SI-PI2 I

This abstract is available from: http://www.jiasociety.org/content/I I/SI/PI2I

(c) 2008 Davis et al; licensee BioMed Central Ltd.

\section{Background}

Highly effective antiretroviral (ARV) therapy has resulted in improved patient (pt) longevity, but many ARV regimens are associated with increases in blood lipid markers, raising concern with the potential for premature atherosclerosis and coronary artery disease. Prior studies with NVP in ARV-naïve pts noted an increase in low-density lipoprotein cholesterol (LDL-C) and triglycerides (TGs), although less significant than the high-density lipoprotein cholesterol (HDL-C) increase. The contribution of the NRTI backbone to this effect was unclear.

\section{Methods}

To address this, 39 pts were randomly chosen to participate in a lipid substudy of the Cell Cycle Independent ARV Therapy (CCIAT) trial; pts $(\mathrm{N}=54: 67 \%$ men, $95 \%$ African-American) received NVP $200 \mathrm{mg}$ twice daily in combination with once-daily tenofovir/emtricitabine (TDF/FTC) 300/200 mg in this trial which was designed to investigate the efficacy and safety of this regimen.

\section{Summary of results}

At baseline, mean total cholesterol (TC), HDL-C, LDL-C, and TG were $168 \mathrm{mg} / \mathrm{dL}, 41 \mathrm{mg} / \mathrm{dL}, 94 \mathrm{mg} / \mathrm{dL}$, and 165 $\mathrm{mg} / \mathrm{dL}$, respectively. Pts included in this analysis had statistically significant increases from baseline in mean HDLC levels $(+19.6 \mathrm{mg} / \mathrm{dL}, \mathrm{n}=27 ; \mathrm{p}<0.0001)$ and statistically significant decreases in mean triglyceride levels from baseline $(-46.7, \mathrm{n}=27 ; \mathrm{p}<0.05)$ (See table in Figure 1 ). The increases in mean HDL-C were statistically significant regardless of baseline level $(20-30 \mathrm{mg} / \mathrm{dL}, \mathrm{p}=0.01 ; 31-$ $40 \mathrm{mg} / \mathrm{dL}, \mathrm{p}=0.0007 ;>40 \mathrm{mg} / \mathrm{dL}, \mathrm{p}=0.004)$. For example, 10 pts with HDL-C $>40 \mathrm{mg} / \mathrm{dL}$ who reached week 96 experienced a mean increase from 48 to $75 \mathrm{mg} / \mathrm{dL}$. From baseline to week 96, mean TG levels decreased by 84.4 $\mathrm{mg} / \mathrm{dL}(\mathrm{n}=27 ; \mathrm{p}=0.0001)$. There were no clinically meaningful changes in the LDL-C and TC levels observed in this study.

\section{Conclusion}

The combination of NVP plus TDF/FTC resulted in apparent positive effects on serum lipids, with an increase in HDL-C, decrease in TGs and little change in LDL-C and TC. This regimen might improve the cardiovascular risk profile of pts taking ARV therapy. 


\begin{tabular}{|l|c|c|c|c|c|c|c|c|}
\hline & \multicolumn{6}{|c|}{ Change from Baseline in Lipid Levels (mg/dL) } \\
\hline & \multicolumn{3}{|c|}{ Week 24 } & \multicolumn{2}{|c|}{ Week 48 } & \multicolumn{2}{c|}{ Week 72 } & \multicolumn{3}{c|}{ Week 96 } \\
\hline & $\mathbf{n}$ & Mean (SD) & $\mathbf{n}$ & Mean (SD) & $\mathbf{n}$ & Mean (SD) & n & Mean (SD) \\
\hline Cholesterol & 39 & $\mathbf{8 . 2 ( 3 8 . 3 )}$ & 37 & $2.7(34.2)$ & 35 & $7.3(33.5)$ & 27 & $10.1(33.6)$ \\
\hline Triglycerides & 39 & $-46.7(99.7)^{\circ}$ & 37 & $-70.6(81.6)^{\circ}$ & 35 & $-82.8(75.4)^{\circ}$ & 27 & $-84.4(98.5)^{\circ}$ \\
\hline HDL-c & 39 & $17.7(20.8)^{\circ}$ & 37 & $16.1(18.1)^{\circ}$ & 35 & $19.1(21.8)^{*}$ & 27 & $19.6(16.7)^{\circ}$ \\
\hline LDL-c & 36 & $-2.2(20.4)$ & 36 & $1.3(27.4)$ & 34 & $4.4(24.7)$ & 26 & $7.5(25.6)$ \\
\hline
\end{tabular}

HDL-c, high-density lipopratein cholesterol; LDL-c. low density lipoprotein cholesteral

$\bullet P \propto 0.05$

Figure I

Publish with Bio Med Central and every scientist can read your work free of charge

"BioMed Central will be the most significant development for disseminating the results of biomedical research in our lifetime."

Sir Paul Nurse, Cancer Research UK

Your research papers will be:

- available free of charge to the entire biomedical community

- peer reviewed and published immediately upon acceptance

- cited in PubMed and archived on PubMed Central

- yours - you keep the copyright
BioMedcentral 